\title{
Evaluasi Galur Harapan Padi Hitam (Oryza sativa L.) Berdaya Hasil Tinggi dan Berumur Genjah
}

\section{Evaluation of Rice Promising Lines of High Yielding and Early Ripening of Black Rice (Oryza sativa L.)}

\author{
Sholeh Udin Al Ghifari ${ }^{1)}$, Supriyanta ${ }^{1 *}$, Panjisakti Basunanda'), Taufan Alam ${ }^{1)}$, M. Habib \\ Widyawan'), Taryono1), dan Kristamtini'2) \\ 1) Departemen Budidaya Pertanian, Fakultas Pertanian, Universitas Gadjah Mada \\ Jalan Flora No. 1, Bulaksumur, Kabupaten Sleman, Yogyakarta 55281 \\ 2) Balai Pengkajian Teknologi Pertanian (BPTP), Yogyakarta \\ Jalan Stadion Maguwoharjo No. 22, Karangsari, Wedomartani, Kec. Ngemplak, \\ Kabupaten Sleman, Yogyakarta 55584 \\ *) Penulis untuk korespodensi E-mail: anta_supri@yahoo.com \\ Diajukan: 15 April 2019 /Diterima: 1 April 2021 /Dipublikasi: 25 Mei 2021
}

\begin{abstract}
Rice is one of the world is important food comodities. One of the rice varieties is black rice, which has been yet widely genetically modified, this causes the low yield of black rice with long life expectancy up to now. The research aims to characterize rice promising lines of high yielding and early ripening of black rice. The field experiment was executed at Pusat Inovasi Agro Teknologi (PIAT) of Gadjah Mada University situated in Kalitirto, Berbah, Sleman, Regency, Yogyakarta Special Territory started from March to August 2018. The 17 rice promising lines and 1 lokal superior variety were used, arranged in the Simple Lattice Design with 3 replications. Each promising line was planted in $5 \times 1.2 \mathrm{~m}$ plot with $20 \times 30 \mathrm{~cm}$ spacing following inling planting procedures. The observation focused on agronomic variables, physical characteristics of rice and grain. Analysis of variance was performed for quantitative traits with $\alpha=5 \%$, followed by Scott Knott test. The research showed that the agronomic character of black rice promising line similar to that of white rice and red rice with resepect to chacarters of plant height (less than $110 \mathrm{~cm}$ ), productive tillers number $(10-20$ tiller), harvesting date (125-150 day after seedling), panicle length $(20-30 \mathrm{~cm})$, number of grain per panicle (less than 250 seeds). The black rice promising line of P2 (4.10 \pm 0.27 tons/hectare) and $X I$ (3.95 \pm 0.45 tons/hectare) gave the higher grain yield that of Sleman Merah $(3.84 \pm 0.50$ tons/hectare). The promising line of $W(116 \pm 0.33$ day after seedling) is the only early-ripening promising line.
\end{abstract}

Keywords: black rice; early ripening; high yielding; white rice

\section{INTISARI}

Padi merupakan komoditas pangan penting dunia. Salah satu jenis padi adalah padi hitam yang saat ini belum banyak direkayasa, sehingga daya hasilnya rendah dengan umur yang panjang. Penelitian ini bertujuan mengetahui karakter agronomi galur harapan padi hitam berdaya hasil tinggi dan berumur genjah. Percobaan dilaksanakan di Pusat Inovasi Agro Teknologi (PIAT) Universitas Gadjah Mada di Kalitirto, Berbah, Kabupaten Sleman, Daerah Istimewa Yogyakarta pada bulan Maret-Agustus 2018. Bahan penelitian yang digunakan adalah 17 galur harapan padi dan 1 kultivar unggul lokal. Rancangan percobaan lapangan yang digunakan adalah Kisi Sederhana (Simple Lattice Design) dengan 3 ulangan. Setiap galur harapan ditanam pada plot berukuran $5 \times 1,2 \mathrm{~m}$ dengan jarak tanam $20 \times 30 \mathrm{~cm}$, secara 
inling (1 bibit perlubang tanam) dengan umur pindah tanam 21 hari. Variabel pengamatan berupa komponen agronomi, komponen hasil dan karakter fisik gabah dan beras. Analisis varians dilakukan untuk variabel kuantitatif dengan taraf nyata $\alpha=5 \%$. dilanjutkan dengan uji Scott Knott. Hasil penelitian menunjukan karakter agronomi galur harapan padi hitam secara umum serupa dengan karakter agronomi galur harapan padi putih dan padi merah terkait dengan variabel tinggi tanaman sedang (lebih dari $110 \mathrm{~cm}$ ), anakan produktif sedang (10-20 buah), umur panen sedang (125-150 HSS), panjang malai $(20-30 \mathrm{~cm})$, jumlah gabah per malai kurang dari 250 biji. Daya hasil galur harapan padi hitam P2 $(4,10 \pm 0.27$ ton/hektare) dan XI $(3,95 \pm 0.45$ ton/hektare) lebih tinggi dari varietas unggul lokal Sleman Merah $(3,84 \pm 0.50$ ton/hektare. Galur harapan padi hitam W (116 \pm 0.33 HSS) memiliki kategori umur panen genjah.

Kata kunci: daya hasil; genjah; padi putih; padi hitam

\section{PENDAHULUAN}

Secara garis besar ada tiga warna beras pada padi, yaitu beras merah (red rice), beras hitam (black rice), dan beras putih (white rice), tetapi sebagian besar beras yang dikonsumsi ialah beras putih (Chaudhary, 2003). Beras hitam merupakan salah satu jenis beras yang dikonsumsi bukan sebagai makanan pokok. Pada saat ini beras hitam dengan kandungan antosianin yang tinggi, mulai populer dikonsumsi sebagai pangan fungsional. Pangan fungsional merupakan pangan yang secara alami atau melalui proses tertentu mengandung satu atau lebih senyawa yang dianggap mempunyai fungsi-fungsi fisiologis yang bermanfaat bagi kesehatan (Kristamtini et al., 2015a).

Produktivitas yang rendah dan umur panen yang panjang merupakan faktor pembatas yang dapat menyebabkan minat petani untuk menanam padi hitam semakin rendah sehingga dikhawatirkan akan menyebabkan kurangnya ketersediaan beras hitam dan merah. Menurut Kristamtini et al. (2015b) padi beras hitam yang merupakan kultivar lokal memiliki kekurangan diantaranya umur tanaman relatif lebih panjang, habitus tanaman lebih tinggi dan produksi yang relatif lebih rendah dibandingkan dengan padi beras putih pada umumnya.

Pengembangan pemuliaan padi hitam dalam skala yang lebih luas menjadi kebutuhan saat ini. Usaha untuk memperbaiki varietas padi hitam terutama dari segi daya hasilnya perlu dilakukan untuk mempertahankan keberlanjutan produksi padi hitam. Pada tahapan pelepasan suatu kultivar, galur-galur yang telah dihasilkan dari proses pemuliaan harus melalui serangkaian proses atau tahapan pengujian seperti karakterisasi atau observasi, uji daya hasil pendahuluan, uji daya hasil lanjutan dan uji multilokasi. Karakterisasi suatu galur harapan padi merupakan salah satu tahapan pengujian yang penting dalam proses pemuliaan tanaman yang nantinya bertujuan untuk pelepasan suatu varietas padi hitam baru.

Saat ini Fakultas Pertanian, UGM mempunyai koleksi plasma nutfah padi hitam yang sebagian besar telah disilangkan dan disaring sehingga menghasilkan beberapa galur harapan. Karakterisasi akan menghasilkan data berisi informasi tentang sifat-sifat dari karakter morfologis dan agronomis galur harapan padi hitam. Karakterisasi dapat memberikan gambaran apakah galur harapan padi hitam koleksi 
Fakultas Pertanian UGM ini siap untuk dilepas menjadi varietas padi hitam baru atau tidak. Dengan begitu, penting dilakukannya karakterisasi yang berguna untuk pendaftaran galur-galur harapan padi hitam baru koleksi Fakultas Pertanian, Universitas Gadjah Mada.

\section{BAHAN DAN METODE}

Penelitian dilaksanakan di Pusat Inovasi Agro Teknologi (PIAT) Universitas Gadjah Mada di Kalitirto, Berbah, Kabupaten Sleman, DIY. Percobaan lapangan dilaksanakan selama Maret-Agustus 2018. Penelitian menggunakan 17 galur harapan padi dan 1 kultivar unggul lokal. Bahan lain yang digunakan adalah pupuk Urea, SP-36, KCl. Peralatan yang digunakan adalah alat dan sarana produksi pertanian untuk pertanaman padi, meteran, kantong plastik, timbangan elektrik, oven, alat tulis, kamera. Percobaan lapangan menggunakan rancangan Simple Lattice Design dengan tiga ulangan. Setiap ulangan terdiri atas tiga blok, satu blok memuat enam galur harapan padi. Setiap nomor aksesi ditanam pada lahan seluas 5 × 1,2 $\mathrm{m}$ dan jarak tanam $20 \times 30 \mathrm{~cm}$.

Pengolahan lahan dilakukan menggunakan traktor tangan dan dilakukan pemupukan dasar menggunakan pupuk kandang dengan dosis 1 ton.ha-1 Persemaian dilakukan hingga benih berumur 21 hari setelah semai. Penanaman dilakukan dengan sistem pindah tanam dan setiap lubang tanam terdiri atas 1 bibit. Dosis pemupukan yang digunakan yaitu $300 \mathrm{~kg} / \mathrm{ha}$ Urea, $200 \mathrm{~kg} / \mathrm{ha}$ SP36, dan $100 \mathrm{~kg} / \mathrm{ha}$ $\mathrm{KCl}$. Pemupukan diaplikasikan pada umur 7 hari setelah tanam (hst) menggunakan $1 / 3$ dosis urea, dosis SP36, dan 1 dosis $\mathrm{KCl}$, kemudian pada 30 dan 49 hst masing-masing mengguna- kan 1/3 dosis urea. Pengairan diberikan dengan penggenangan lahan seminggu sekali. Pengendalian OPT disesuai-kan dengan kondisi gejala serangan dilapangan. Pengendalian gulma dengan cara manual dilakukan sesuai dengan kondisi gulma dilapangan. Panen dilakukan saat $90 \%$ bulir padi sudah menguning .

Pengamatan dilakukan pada delapan tanaman sampel pada masing-masing satuan percobaan. Pengamatan terdiri pada dua komponen yaitu, komponen agronomis (tinggi tanaman, lebar daun, panjang daun, umur berbunga dan umur panen), dan komponen hasil (anakan produktif, panjang malai, gabah isi/ malai, gabah hampa/malai, kepadatan malai, berat 100 butir dan produktivitas). Data kuantitatif mengenai variabel pengamatan yang didapat dianalisis dengan ANOVA pada taraf nyata $\alpha=5 \%$ menggunkaan program SAS (Statistical Analysis System). Apabila terdapat perbedaan yang nyata, maka akan diuji lanjut dengan Scott Knott untuk mengetahui perbedaan antar perlakuan. Model aditif untuk rancangan yang digunakan adalah:

$$
Y_{i j l}=\mu+\gamma_{\mathrm{j}}+\rho_{l(j)}+\tau_{\mathrm{i}}+\varepsilon_{i j l}
$$

Keterangan:

$$
\begin{array}{ll}
M & =\text { Rerata umum, } \\
\gamma_{\mathrm{j}} & =\text { pengaruh ulangan, } \\
\tau_{\mathrm{i}} & =\text { Pengaruh perlaku, } \\
\rho_{l(j)} & =\text { pengaruh blok dalam ulangan, } \\
\varepsilon_{\mathrm{ijl}} & =\text { sesatan. }
\end{array}
$$

\section{HASIL DAN PEMBAHASAN}

Pertumbuhan ditandai dengan adanya peningkatan jumlah sel serta peningkatan ukuran sehingga terjadi perubahan penampilan pada tanaman yang tidak bisa kembali 
(irreversible). Variabel pengamatan yang mencerminkan pertumbuhan disajikan dalam Tabel 1. Galur harapan putih AT $(156,33 \pm 4,78$ $\mathrm{cm}$ ) merupakan galur dengan tinggi tanaman tertinggi dan berbeda nyata dengan galur harapan padi lainnya. Berdasarkan klasifikasi tinggi tanaman padi Komnas Plasma Nutfah (2003) galur harapan padi hitam memiliki kriteria pendek (kurang dari $110 \mathrm{~cm}$ ) kecuali galur harapan padi hitam W $(110,47 \pm 7,17 \mathrm{~cm})$. Galur harapan padi hitam memiliki tinggi tanaman tidak berbeda nyata Kultivar lokal Sleman Merah dan galur harapan AA Gundil. Banyaknya galur harapan padi hitam yang diuji menunjukkan kriteria tinggi tanaman yang pendek dan diharapkan akan lebih tahan terhadap rebah, sehingga galur tersebut lebih potensial untuk dikembangkan menjadi varietas baru. Menurut Yahumri et al. (2015) tanaman padi yang pendek biasanya tahan rebah sehingga akan mengurangi kegagalan panen.

Tabel 1. Tinggi Tanaman, Panjang Daun Bendera, Lebar Daun Bendera 17 Galur Harapan Padi dan 1 Kultivar Unggul Lokal.

\begin{tabular}{|c|c|c|c|c|c|c|c|c|c|}
\hline \multirow{2}{*}{$\begin{array}{c}\text { No } \\
1\end{array}$} & \multirow{2}{*}{$\begin{array}{l}\text { Galur } \\
60\end{array}$} & \multirow{2}{*}{$\begin{array}{c}\text { Warna } \\
\text { Beras }\end{array}$} & \multicolumn{2}{|c|}{$\begin{array}{l}\text { Tinggi Tanaman } \\
(\mathrm{cm})\end{array}$} & \multirow{2}{*}{$\begin{array}{c}\text { Kriteria } \\
\text { Tinggi } \\
\text { Tanaman } \\
\text { Pendek }\end{array}$} & \multicolumn{2}{|c|}{$\begin{array}{l}\text { Panjang Daun } \\
\text { Bendera }(\mathrm{cm})\end{array}$} & \multicolumn{2}{|c|}{$\begin{array}{l}\text { Lebar Daun } \\
\text { Bendera }(\mathrm{cm})\end{array}$} \\
\hline & & & $88,37 \pm 1$ & $b$ & & $30,00 \pm 2.80$ & $b$ & 1,80 & \\
\hline 2 & AA Bulu & Putih & $90,60 \pm 2.45$ & $b$ & Pendek & $24,40 \pm 1.77$ & b & $1,23 \pm 0.09$ & \\
\hline 3 & $A C$ & Putih & $84,43 \pm 7.87$ & $b$ & Pendek & $25,83 \pm 6.25$ & $b$ & $1,67 \pm 0.66$ & \\
\hline 4 & AT & Putih & $156,33 \pm 4.78$ & $a$ & Tinggi & $34,23 \pm 6.07$ & $\mathrm{a}$ & $2,10 \pm 0.70$ & \\
\hline 5 & $E$ & Putih & $100,27 \pm 9.37$ & $\mathrm{~b}$ & Pendek & $32,67 \pm 4.62$ & a & & \\
\hline 6 & $\mathrm{BC}$ & & $99,03 \pm 5.67$ & $b$ & Pendek & & a & & \\
\hline 7 & $\mathrm{H} 63$ & Merah & $101,1 \pm 10.84$ & $b$ & Pendek & 3.84 & a & & \\
\hline 8 & AP & Merah & $98,20 \pm 10.20$ & $b$ & Pendek & $38,30 \pm 2.88$ & a & 1,80 & \\
\hline 9 & IC & Hitam & $102,37 \pm 3.81$ & $b$ & Pendek & $37,33 \pm 2.10$ & a & .03 & \\
\hline 10 & $\mathrm{~A} 2$ & Hitam & $85,17 \pm 2.14$ & $\mathrm{~b}$ & Pendek & 34,9 & a & .09 & \\
\hline 11 & W & & $110,47 \pm$ & $b$ & Sedang & & $b$ & & \\
\hline 12 & $\mathrm{P} 2$ & Hitam & $97,90 \pm 2.97$ & $b$ & Pendek & $30,47 \pm 5.68$ & $b$ & $1,47 \pm 0.09$ & \\
\hline 13 & $\mathrm{BD}$ & Hitam & $101,03 \pm 6.29$ & $b$ & Pendek & $29,80 \pm 7.03$ & $b$ & $1,47 \pm 0.24$ & \\
\hline 14 & BB & Hitam & $91,20 \pm 3.63$ & $\mathrm{~b}$ & Pendek & $28,40 \pm 2.53$ & $b$ & $1,53 \pm 0.12$ & \\
\hline 15 & $X I$ & Hitam & $100,47 \pm 13.3$ & $b$ & Pendek & $38,27 \pm 4.78$ & $\mathrm{a}$ & $1,67 \pm 0.21$ & \\
\hline 16 & AAS & Merah & $100,47 \pm 5.30$ & $b$ & Pendek & $22,67 \pm 4.36$ & $b$ & $1,37 \pm 0.11$ & \\
\hline 17 & AA Gundil & Putih & $111,80 \pm 7.72$ & $b$ & Sedang & $27,47 \pm 1.48$ & $b$ & $1,77 \pm 0.17$ & \\
\hline 18 & Sleman Merah & Merah & $102,93 \pm 9.69$ & $\mathrm{~b}$ & Pendek & $19,00 \pm 5.69$ & $b$ & $1,37 \pm 0.22$ & a \\
\hline
\end{tabular}

Keterangan: Angka yang diikuti dengan huruf yang sama pada kolom yang sama tidak berbeda nyata berdasarkan uji Scott Knott pada taraf nyata $5 \%$. Tanda \pm diikuti angka dibelakangnya menunjukkan nilai standar deviasi.

Pada pengamatan panjang daun bendera, jang dibandingkan galur harapan lainnya. galur harapan padi hitam XI $(38,27 \pm 4.78 \mathrm{~cm})$, Berdasarkan hasil uji lanjut galur-galur harapan padi merah $\mathrm{BC}(43,77 \pm 2.09 \mathrm{~cm})$, dan $\mathrm{H} 630$ padi yang memiliki panjang daun bendera lebih $(38,73 \pm 3.84 \mathrm{~cm})$ memiliki daun bendera terpan- dari $32,67 \mathrm{~cm}$ menunjukkan berbeda nyata 
terhadap galur harapan padi dengan panjang daun bendera kurang dari $32,67 \mathrm{~cm}$. Pada variabel pengamatan lebar daun bendera menunjukkan hasil tidak berbeda nyata pada semua galur harapan padi dan kultivar pembanding. Galur-galur harapan padi hitam dengan panjang daun bendera lebih dari 32,67 cm (IC, A2, XI, AP), diduga lebih potensial untuk dikembangkan menjadi varietas unggul baru. Dere dan Yildirim (2006) mengatakan bahwa daun bendera berpengaruh terhadap daya hasil karena daun bendera berperan sebagai distributor asimilat hasil fotosintesis kemalai.

Tabel 2. Umur Berbunga dan Umur Panen 17 Galur Harapan Padi dan 1 Kultivar Unggul Lokal.

\begin{tabular}{|c|c|c|c|c|c|c|c|}
\hline \multirow{2}{*}{$\frac{\text { No }}{1}$} & \multirow{2}{*}{$\begin{array}{r}\text { Galur } \\
\mathrm{H} 360\end{array}$} & \multirow{2}{*}{$\begin{array}{c}\text { Warna } \\
\text { Beras } \\
\text { Putih }\end{array}$} & \multicolumn{2}{|c|}{$\begin{array}{l}\text { Umur Berbunga } \\
\text { (HSS) }\end{array}$} & \multicolumn{2}{|c|}{$\begin{array}{l}\text { Umur Panen } \\
\text { (HSS) }\end{array}$} & \multirow{2}{*}{$\begin{array}{c}\begin{array}{c}\text { Kriteria Umur } \\
\text { Panen }\end{array} \\
\text { Sedang }\end{array}$} \\
\hline & & & $95,33 \pm 4.62$ & $\mathrm{~b}$ & $132 \pm 0.00$ & $a$ & \\
\hline 2 & AA Bulu & Putih & $90,67 \pm 6.35$ & $c$ & $127 \pm 0.00$ & $\mathrm{c}$ & Sedang \\
\hline 3 & $A C$ & Putih & $83 \pm 1.73$ & $d$ & $116 \pm 0.00$ & $d$ & Genjah \\
\hline 4 & AT & Putih & $89 \pm 1.73$ & $\mathrm{C}$ & $129 \pm 1.73$ & $\mathrm{c}$ & Sedang \\
\hline 5 & $E$ & Putih & $84 \pm 1.73$ & $d$ & $116 \pm 0.00$ & $d$ & Genjah \\
\hline 6 & $\mathrm{BC}$ & Merah & $82 \pm 3.00$ & $d$ & $116 \pm 0.00$ & $d$ & Genjah \\
\hline 7 & $\mathrm{H} 630$ & Merah & $80 \pm 1.73$ & $d$ & $114 \pm 0.00$ & $\mathrm{e}$ & Genjah \\
\hline 8 & AP & Hitam & $92,67 \pm 4.62$ & $\mathrm{c}$ & $130 \pm 0.00$ & $b$ & Sedang \\
\hline 9 & IC & Hitam & $89 \pm 9.54$ & $c$ & $132 \pm 0.00$ & $\mathrm{a}$ & Sedang \\
\hline 10 & $\mathrm{~A} 2$ & Hitam & $102,67 \pm 4.04$ & $\mathrm{a}$ & $130,33 \pm 2.89$ & $b$ & Sedang \\
\hline 11 & W & Hitam & $79 \pm 0.00$ & $d$ & $116 \pm 0.00$ & $d$ & Genjah \\
\hline 12 & $\mathrm{P} 2$ & Hitam & $90,67 \pm 6.35$ & $c$ & $129 \pm 1.73$ & $\mathrm{C}$ & Sedang \\
\hline 13 & $\mathrm{BD}$ & Hitam & $82 \pm 0.00$ & $d$ & $130 \pm 0.00$ & $b$ & Sedang \\
\hline 14 & BB & Hitam & $88,33 \pm 2.89$ & $c$ & $128 \pm 1.73$ & $c$ & Sedang \\
\hline 15 & $X I$ & Hitam & $97,67 \pm 7.51$ & $b$ & $132 \pm 0.00$ & $\mathrm{a}$ & Sedang \\
\hline 16 & AAS & Merah & $79 \pm 0.00$ & $\mathrm{~d}$ & $114 \pm 0.00$ & $\mathrm{e}$ & Genjah \\
\hline 17 & AA Gundil & Putih & $83,67 \pm 2.89$ & $d$ & $116 \pm 0.00$ & $d$ & Genjah \\
\hline 18 & Sleman Merah & Merah & $80 \pm 1.73$ & $d$ & $114 \pm 0.00$ & $\mathrm{e}$ & Genjah \\
\hline
\end{tabular}

Keterangan: Angka yang diikuti dengan huruf yang sama pada kolom yang sama tidak berbeda nyata berdasarkan uji Scott Knott pada taraf nyata 5\%. Tanda \pm diikuti angka dibelakangnya menunjukkan nilai standar deviasi.

Variabel pengamatan umur berbunga dan umur panen disajikan dalam Tabel 2. Umur berbunga diamati ketika tanaman telah berbunga $80 \%$. Galur harapan padi hitam A2 $(102,67 \pm 4.04$ HSS) memiliki umur berbunga paling lama dan menunjukkan hasil berbeda nyata terhadap galur-galur harapan padi lainnya. Galur harapan padi hitam yang memiliki umur berbunga terpendek adalah galur harapan padi hitam W (79 HSS).

Umur panen merupakan salah satu karakter yang diperhitungkan dalam pemuliaan padi hitam karena varietas padi hitam yang sudah ada umumnya memiliki umur panen yang panjang. Berdasarkan klasifikasi umur panen BB Padi (2015) pada penelitian ini didapat dua kriteria umur panen yaitu sedang (125-150 HSS) 
dan genjah (lebih dari 105-124 HSS). Galur harapan padi hitam $\mathrm{W}$ merupakan satu-satunya galur harapan padi hitam yang memiliki umur panen genjah (114 HSS) dan berpotensi untuk dikembangkan karena memiliki umur panen genjah. Umur panen genjah merupakan karakter penting dalam pengembangan varietas padi hitam baru, mengingat padi hitam lokal yang ada memiliki umur panen yang panjang.

Tabel 3. Jumlah Anakan Produktif 17 Galur Harapan Padi dan 1 Kultivar Unggul Lokal.

\begin{tabular}{llllll}
\hline No & Galur & Warna Beras & \multicolumn{2}{c}{ Anakan Produktif (buah) } & $\begin{array}{c}\text { Kriteria Anakan } \\
\text { Produktif }\end{array}$ \\
\hline 1 & H360 & Putih & $16,93 \pm 1.42$ & $\mathrm{~b}$ & Sedang \\
2 & AA Bulu & Putih & $16,40 \pm 0.33$ & $\mathrm{~b}$ & Sedang \\
3 & AC & Putih & $22,83 \pm 4.02$ & $\mathrm{a}$ & Banyak \\
4 & AT & Puth & $13,63 \pm 3.05$ & $\mathrm{~b}$ & Sedang \\
5 & E & Putih & $12,63 \pm 2.02$ & $\mathrm{~b}$ & Sedang \\
6 & BC & Merah & $14,73 \pm 3.76$ & $\mathrm{~b}$ & Sedang \\
7 & H630 & Merah & $13,77 \pm 0.25$ & $\mathrm{~b}$ & Sedang \\
8 & AP & Hitam & $13,93 \pm 2.98$ & $\mathrm{~b}$ & Sedang \\
9 & IC & Hitam & $15,33 \pm 2.48$ & $\mathrm{~b}$ & Sedang \\
10 & A2 & Hitam & $15,23 \pm 2.26$ & $\mathrm{~b}$ & Sedang \\
11 & W & Hitam & $13,73 \pm 2.63$ & $\mathrm{~b}$ & Sedang \\
12 & P2 & Hitam & $16,77 \pm 3.13$ & $\mathrm{~b}$ & Sedang \\
13 & BD & Hitam & $14,80 \pm 0.95$ & $\mathrm{~b}$ & Sedang \\
14 & BB & Hitam & $15,50 \pm 0.98$ & $\mathrm{~b}$ & Sedang \\
15 & XI & Hitam & $14,47 \pm 2.06$ & $\mathrm{~b}$ & Sedang \\
16 & AAS & Merah & $15,53 \pm 3.69$ & $\mathrm{~b}$ & Sedang \\
17 & AA Gundil & Putih & $11,87 \pm 2.71$ & $\mathrm{~b}$ & Kurang \\
18 & Sleman Merah & Merah & $22,13 \pm 0.82$ & $\mathrm{a}$ & Banyak \\
\hline
\end{tabular}

Keterangan: Angka yang diikuti dengan huruf yang sama pada kolom yang sama tidak berbeda nyata berdasarkan uji Scott Knott pada taraf nyata 5\%.

Jumlah anakan produktif per rumpun diharapkan berkontribusi terhadap hasil padi karena dengan semakin banyak jumlah anakan produktif per rumpun maka semakin banyak malai yang dihasilkan. Tabel 3 menunjukan galur harapan padi putih AC $(22,83 \pm 4.02$ buah) dan Kultivar lokal Sleman Merah $(22,13 \pm 0.82$ buah) memiliki anakan produktif berkriteria banyak dan berbeda nyata terhadap galur harapan padi lainnya. Galur harapan padi hitam masuk dalam kriteria sedang (12-20 batang per rumpun). Jika dibandingkan kultivar lokal Sleman Merah jumlah anakan produktif galur harapan padi hitam masih terlalu kecil.

Galur harapan padi hitam masih bisa dikembangkan menjadi varietas padi hitam walaupun mempunyai anakan produktif sedang. Menurut Abdullah et al. (2008) menjelaskan bahwa padi tipe baru (PTB) merupakan padi yang mempunyai arsitektur atau tipe baru memiliki jumlah anakan sedang (9-12 anakan) dan semua produktif. Kemam-puan tanaman 
padi membentuk anakan diduga secara genetik berbeda. Namun demikian faktor lingkungan dan cara budidaya berpengaruh terhadap jumlah anakan, sesuai dengan penjelasan Yoshida (1981) jumlah anakan dipengaruhi oleh jarak tanam, cahaya, pasokan hara, dan faktor lingkungan lain serta kondisi kultur yang mempengaruhi anakan.

Panjang malai biasanya berhubungan dengan hasil tanaman padi di mana semakin panjang malai diharapkan semakin banyak jumlah gabah total. Galur harapan padi hitam XI $(30,55 \pm 0.86 \mathrm{~cm})$ satu-satunya galur yang termasuk kriteria panjang dan memiliki jumlah gabah per malai 231,45 biji. Sedangkan galur harapan padi hitam lainnya masuk kedalam kriteria sedang (20-30 cm) berdasarkan klasifi-kasi panjang malai Sajak (2012). Hasil uji lanjut Scott Knott pada karakter panjang malai menun-jukan galur harapan padi hitam XI, AP, IC, padi merah H630, BC, dan galur padi putih H360 berbeda nyata dengan galur harapan lainnya.

Galur harapan padi hitam yang memiliki persentase gabah hampa kurang dari 20\% hanya galur harapan padi hitam IC. Galur-galur harapan padi hitam $P 2, A 2, A, W, B D, B B, X I$ menunjukkan persentase gabah hampa per malai lebih dari $20 \%$ sedangkan menurut Vergara (1995) varietas unggul dicirikan memiliki persentase gabah isi lebih dari $80 \%$ dan persentase gabah hampa kurang dari $20 \%$. Melihat hal tersebut sebenarnya ada potensi gabah-gabah hampa tersebut menjadi gabah isi dan dapat meningkatkan daya hasil padi.

Penyebab banyaknya persentase gabah hampa pada galur harapan yang diuji diduga faktor genetik dari galur tersebut dan pengaruh lingkungan. Nilai heritabilitas variabel gabah hampa sebesar 0,80 (Tabel 6) dan masuk dalam kriteria tinggi. Nilai heritabilitas tinggi menunjukkan bahwa pengaruh genetik lebih dominan mempengaruhi penampilan fenotip. Faktor lingkungan yang diduga berpengaruh terhadap banyaknya gabah hampa adalah serangan hama walang sangit (Leprocorisa acuta). Walang sangit menyerang saat fase masak susu dan menyebabkan pengisian bulir tidak sempurna dan akhirnya gabah tidak terisi penuh atau hampa. Pengendalian hama walang sangit harus diperhatikan untuk mendapatkan hasil yang maksimal pada tanaman padi. Suprihatno dan Darajat (2008) menambahkan, potensi hasil maksimum dari suatu varietas sering tidak tercapai karena fotosintat yang akan disimpan pada gabah sering dimanfaatkan oleh hama atau penyakit tanaman.

Pada pengamatan kepadatan malai menunjukkan galur yang memiliki kepadatan malai terbaik akan memiliki jumlah gabah isi per malai yang baik. Galur harapan padi putih $E$ (8,67 $\pm 1.51 \mathrm{bij} / \mathrm{cm})$, H360 $(8,20 \pm 1.67 \mathrm{biji} / \mathrm{cm})$, galur harapan padi merah H630 $(8,00 \pm 1.64$ biji/cm), galur harapan padi hitam XI $(7,60 \pm 1.48$ $\mathrm{biji} / \mathrm{cm})$ dan galur AA Gundil $(8,57 \pm 1.84 \mathrm{biji} / \mathrm{cm})$ memiliki kepadatan malai terbaik dan menghasilkan jumlah gabah per malai terbaik (lebih dari 220 biji). Berdasarkan hasil uji lanjut karakter kepadatan malai dan jumlah gabah per malai pada galur-galur harapan tersebut berbedanya terhadap galur lainnya. Kultivar lokal Sleman Merah merupakan galur dengan kepadatan malai terkecil $5,07 \pm 1.59 \mathrm{biji} / \mathrm{cm}$ dan jumlah gabah per malai terkecil 112,53 biji. 
Tabel 4. Panjang Malai, Gabah Isi Permalai, Gabah Hampa Permalai, Jumlah Gabah Permalai dan Kepadatan Malai 17 Galur Harapan Padi dan 1 Kultivar Unggul Lokal.

\begin{tabular}{|c|c|c|c|c|c|c|c|c|}
\hline No & Galur & $\begin{array}{l}\text { Warna } \\
\text { Beras }\end{array}$ & $\begin{array}{l}\text { Panjang } \\
\text { Malai } \\
\text { (cm) }\end{array}$ & $\begin{array}{c}\text { Kriteria } \\
\text { Panjang } \\
\text { Malai }\end{array}$ & $\begin{array}{c}\text { Gabah Isi } \\
\text { Per malai } \\
\text { (Biji) }\end{array}$ & $\begin{array}{c}\text { Gabah } \\
\text { Hampa } \\
\text { Per malai } \\
(\%)\end{array}$ & $\begin{array}{l}\text { Jumlah } \\
\text { Gabah Per } \\
\text { malai (Biji) }\end{array}$ & $\begin{array}{c}\text { Kepadatan } \\
\text { Malai } \\
\text { (Biji/cm) }\end{array}$ \\
\hline
\end{tabular}

\begin{tabular}{|c|c|c|c|c|c|c|c|c|c|c|c|c|c|}
\hline 1 & H360 & Putih & $\begin{array}{c}29,41 \pm \\
0.81\end{array}$ & $A$ & Sedang & $\begin{array}{c}176,54 \pm \\
16.36\end{array}$ & $\mathrm{a}$ & 26.34 & $b$ & $\begin{array}{c}240.49 \pm \\
54.79\end{array}$ & $a$ & $\begin{array}{c}8,20 \pm \\
1.67\end{array}$ & $a$ \\
\hline 2 & $\begin{array}{l}\text { AA } \\
\text { Bulu }\end{array}$ & Putih & $\begin{array}{c}26,22 \pm \\
0.58\end{array}$ & C & Sedang & $\begin{array}{c}111,70 \pm \\
34.99\end{array}$ & b & 19.65 & $c$ & $\begin{array}{c}139.29 \pm \\
18.88\end{array}$ & d & $\begin{array}{c}5,30 \pm \\
1.58\end{array}$ & $c$ \\
\hline 3 & $A C$ & Putih & $\begin{array}{c}23,79 \pm \\
1.40\end{array}$ & $\mathrm{D}$ & Sedang & $\begin{array}{c}99,63 \pm 1 \\
7.00\end{array}$ & $b$ & 12.46 & $c$ & $\begin{array}{c}114.64 \pm \\
15.70\end{array}$ & $d$ & $\begin{array}{c}4,80 \pm \\
1.68\end{array}$ & c \\
\hline 4 & AT & Putih & $\begin{array}{c}27,04 \pm \\
0.76\end{array}$ & $B$ & Sedang & $\begin{array}{c}117,65 \pm \\
11.56\end{array}$ & $b$ & 31.04 & b & $\begin{array}{c}169.67 \pm \\
32.75\end{array}$ & $c$ & $\begin{array}{c}6,27 \pm \\
1.54\end{array}$ & $b$ \\
\hline 5 & $E$ & Putih & $\begin{array}{c}25,86 \pm \\
0.90\end{array}$ & $C$ & Sedang & $\begin{array}{c}160,75 \pm \\
20.79\end{array}$ & $a$ & 26.34 & b & $\begin{array}{c}224.47 \pm \\
39.33\end{array}$ & $a$ & $\begin{array}{c}8,67 \pm \\
1.51\end{array}$ & $a$ \\
\hline 6 & $B C$ & Merah & $\begin{array}{c}29,28 \pm \\
1.31\end{array}$ & A & Sedang & $\begin{array}{c}128,81 \pm \\
28.63\end{array}$ & $\mathrm{~b}$ & 12.81 & c & $\begin{array}{c}184.29 \pm \\
64.80\end{array}$ & b & $\begin{array}{c}6,27 \pm \\
1.58\end{array}$ & b \\
\hline 7 & $\mathrm{H} 630$ & Merah & $\begin{array}{c}29,53 \pm \\
0.67\end{array}$ & $A$ & Sedang & $\begin{array}{c}168,64 \pm \\
25.05\end{array}$ & $a$ & 28.75 & b & $\begin{array}{c}235.92 \pm \\
47.10\end{array}$ & $a$ & $\begin{array}{c}8,00 \pm \\
1.64\end{array}$ & $a$ \\
\hline 8 & AP & Hitam & $\begin{array}{c}28,47 \pm \\
0,29\end{array}$ & A & Sedang & $\begin{array}{c}105,48 \pm \\
16,10\end{array}$ & b & 43.64 & $a$ & $\begin{array}{c}185.52 \pm \\
79.15\end{array}$ & b & $\begin{array}{l}6,50 \pm \\
155\end{array}$ & b \\
\hline 9 & IC & Hitam & $\begin{array}{c}28,62 \pm \\
0.88\end{array}$ & $A$ & Sedang & $\begin{array}{c}105,87 \pm \\
4.14\end{array}$ & $b$ & 18.66 & c & $\begin{array}{c}191.79 \pm \\
62.11\end{array}$ & $b$ & $\begin{array}{c}6,67 \pm \\
1.70\end{array}$ & $b$ \\
\hline 10 & A2 & Hitam & $\begin{array}{c}28,02 \pm \\
0.18\end{array}$ & $B$ & Sedang & $\begin{array}{c}155,64 \pm \\
19.17\end{array}$ & $a$ & 28.40 & b & $\begin{array}{c}191.69 \pm \\
23.21\end{array}$ & $b$ & $\begin{array}{c}6,87 \pm \\
1.62\end{array}$ & $b$ \\
\hline 11 & W & Hitam & $\begin{array}{c}25,67 \pm \\
0.79\end{array}$ & $C$ & Sedang & $\begin{array}{c}91,16 \pm 7 \\
.46\end{array}$ & $b$ & 27.69 & b & $\begin{array}{c}123.74 \pm \\
20.13\end{array}$ & $d$ & $\begin{array}{c}4,83 \pm \\
1.47\end{array}$ & c \\
\hline 12 & P2 & Hitam & $\begin{array}{c}26,84 \pm \\
0.09\end{array}$ & B & Sedang & $\begin{array}{c}139,22 \pm \\
7.45\end{array}$ & $a$ & 27.37 & b & $\begin{array}{c}160.32 \pm \\
16.77\end{array}$ & c & $\begin{array}{c}5,97 \pm \\
1.75\end{array}$ & $b$ \\
\hline 13 & $\mathrm{BD}$ & Hitam & $\begin{array}{c}27,92 \pm \\
1.63\end{array}$ & $B$ & Sedang & $\begin{array}{c}104,18 \pm \\
27.20\end{array}$ & $b$ & 31.45 & b & $\begin{array}{c}157.69 \pm \\
67.21\end{array}$ & $c$ & $\begin{array}{c}5,57 \pm \\
1.72\end{array}$ & c \\
\hline 14 & BB & Hitam & $\begin{array}{c}26,06 \pm \\
1.28\end{array}$ & $C$ & Sedang & $\begin{array}{c}88,53 \pm 1 \\
7.93\end{array}$ & $b$ & 29.85 & b & $\begin{array}{c}122.52 \pm \\
20.74\end{array}$ & $d$ & $\begin{array}{c}4,67 \pm \\
1.51\end{array}$ & $c$ \\
\hline 15 & XI & Hitam & $\begin{array}{c}30,55 \pm \\
0.86\end{array}$ & A & Panjang & $\begin{array}{c}168,24 \pm \\
18.53\end{array}$ & $a$ & 25.45 & b & $\begin{array}{c}231.45 \pm \\
42.99\end{array}$ & $a$ & $\begin{array}{c}7,60 \pm \\
1.48\end{array}$ & $a$ \\
\hline 16 & AAS & Merah & $\begin{array}{c}23,61 \pm \\
1.25\end{array}$ & $\mathrm{D}$ & Sedang & $\begin{array}{c}92,44 \pm 1 \\
4.37\end{array}$ & $b$ & 15.04 & c & $\begin{array}{c}124.17 \pm \\
23.50\end{array}$ & d & $\begin{array}{c}5,23 \pm \\
1.55\end{array}$ & c \\
\hline 17 & $\begin{array}{l}\text { AA } \\
\text { Gundil }\end{array}$ & Putih & $\begin{array}{c}27,30 \pm \\
0.66\end{array}$ & B & Sedang & $\begin{array}{c}180,83 \pm \\
12.69\end{array}$ & $a$ & 43.91 & a & $\begin{array}{c}233.57 \pm \\
39.47\end{array}$ & $a$ & $\begin{array}{c}8,57 \pm \\
1.84\end{array}$ & $a$ \\
\hline 18 & $\begin{array}{l}\text { Sleman } \\
\text { Merah }\end{array}$ & Merah & $\begin{array}{c}22,23 \pm \\
0.62\end{array}$ & $\mathrm{E}$ & Sedang & $\begin{array}{c}95,06 \pm \\
8.68\end{array}$ & $b$ & 21.75 & c & $\begin{array}{c}112.53 \pm \\
19.99\end{array}$ & d & $\begin{array}{c}5,07 \pm \\
1.59 \\
\end{array}$ & C \\
\hline
\end{tabular}

Keterangan: Angka yang diikuti dengan huruf yang sama pada kolom yang sama tidak berbeda nyata berdasarkan uji Scott Knott pada taraf nyata $5 \%$. Tanda \pm diikut angka dibelakangnya menunjukkan nilai standar deviasi.

Pada pengamatan gabah isi per malai galur harapan padi hitam XI, A2, P2, galur harapan padi putih $\mathrm{H} 360$, E, galur harapan padi merah H630 dan galur harapan AA Gundil menunjukan hasil tidak berbeda nyata diantaranya dan berbedanya dengan galur harapan lainnya. Galur harapan padi hitam XI

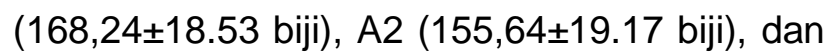
(P2 139,22 \pm 7.45 ) biji merupakan galur yang miliki jumlah gabah isi terbanyak diantara galur harapan padi hitam. Kultivar lokal Sleman Merah $(95,06 \pm 8.68$ biji) memiliki jumlah gabah isi terkecil. Secara keseluruhan tidak ada galur harapan yang menunjukan hasil gabah per malai 250 biji sebagai salah satu syarat padi tersebut dikatakan sebagai varietas unggul (Susanto et al., 2003). Namun pada galur harapan padi hitam terdapat galur yang mendekati hasil 
tersebut yaitu galur padi harapan hitam XI padi hitam P2, A2, galur padi harapan merah (168,24 \pm 18.53 biji). Berdasarkan hasil uji lanjut $\mathrm{H} 630$, galur harapan padi putih $\mathrm{H} 360$, $E$, dan $\mathrm{AA}$ galur tersebut tidak berbeda nyata dengan galur Gundil.

Tabel 5. Bobot 100 biji dan Produktivitas 17 Galur Harapan Padi dan 1 Kultivar Unggul Lokal.

\begin{tabular}{|c|c|c|c|c|c|c|}
\hline No & Galur & Warna Beras & Bobot 100 biji (gr & am) & Produktivitas & on/ha) \\
\hline 1 & H360 & Putih & $1,94 \pm 0.15$ & $d$ & $7,26 \pm 0.52$ & $a$ \\
\hline 2 & AA (Bulu) & Putih & $2,71 \pm 0.13$ & $b$ & $5,41 \pm 0.89$ & a \\
\hline 3 & $A C$ & Putih & $2,37 \pm 0.05$ & c & $5,05 \pm 0.40$ & $a$ \\
\hline 4 & AT & Putih & $2,39 \pm 0.11$ & c & $2,91 \pm 0.29$ & $b$ \\
\hline 5 & $E$ & Putih & $2,21 \pm 0.04$ & c & $6,33 \pm 2.17$ & a \\
\hline 6 & $B C$ & Merah & $2,32 \pm 0.16$ & c & $3,23 \pm 0.54$ & $b$ \\
\hline 7 & $\mathrm{H} 630$ & Merah & $2,14 \pm 0.09$ & $d$ & $4,23 \pm 0.11$ & $b$ \\
\hline 8 & AP & Hitam & $2,23 \pm 0.19$ & c & $2,62 \pm 0.36$ & $b$ \\
\hline 9 & IC & Hitam & $2,18 \pm 0.14$ & c & $2,69 \pm 0.05$ & $b$ \\
\hline 10 & $\mathrm{~A} 2$ & Hitam & $1,99 \pm 0.27$ & $d$ & $3,37 \pm 0.36$ & $b$ \\
\hline 11 & W & Hitam & $2,39 \pm 0.33$ & c & $2,33 \pm 0.31$ & $b$ \\
\hline 12 & P2 & Hitam & $2,37 \pm 0.10$ & c & $4,10 \pm 0.27$ & $b$ \\
\hline 13 & $\mathrm{BD}$ & Hitam & $2,29 \pm 0.20$ & c & $2,78 \pm 0.12$ & $b$ \\
\hline 14 & BB & Hitam & $2,39 \pm 0.13$ & c & $3,27 \pm 0.03$ & $b$ \\
\hline 15 & $X I$ & Hitam & $1,99 \pm 0.21$ & $d$ & $3,95 \pm 0.45$ & $b$ \\
\hline 16 & AAS & Merah & $2,99 \pm 0.16$ & a & $3,35 \pm 0.20$ & $b$ \\
\hline 17 & AA (Gundil) & Putih & $2,35 \pm 0.05$ & c & $3,27 \pm 1.11$ & $b$ \\
\hline 18 & Sleman Merah & Merah & $2,25 \pm 0.22$ & c & $3,84 \pm 0.50$ & $b$ \\
\hline
\end{tabular}

Keterangan: Angka yang diikuti dengan huruf yang sama pada kolom yang sama tidak berbeda nyata berdasarkan uji Scott Knott pada taraf nyata 5\%. Tanda \pm diikut angka dibelakangnya menunjukkan nilai standar deviasi.

Bobot 100 biji menggambarkan kualitas dan ukuran biji. Tabel 5 disajikan galur harapan AAS $(2,99 \pm 0.16$ gram $)$ memiliki bobot 100 biji tertinggi dan berbeda nyata terhadap galuh harapan lainnya. Pada galur harapan padi hitam memiliki bobot tidak berbeda nyata dengan kultivar lokal Sleman Merah kecuali galur harapan padi hitam XI dan A2. Berat 100 butir gabah isi menyatakan banyaknya biomassa yang terkandung dalam gabah. Semakin bernas gabah menandakan biomassa yang terkandung di dalamnya semakin banyak.

Data potensi hasil padi pada Tabel 5 merupakan hasil konversi dari gram per meter menjadi ton per hektare. Galur harapan yang mempunyai produktivitas tertinggi adalah galur padi putih $\mathrm{H} 360$ sebesar $7,26 \pm 0.52$ ton/hektare diikuti galur $E(6,33 \pm 2.17$ ton/hektare), AA Bulu $(5,41 \pm 0.89$ ton/hektare), AC (5,05 \pm 0.40$)$. Galur harapan tersebut menunjukkan hasil beda nyata terhadap galur harapan lain dan kultivar lokal. Kultivar lokal Sleman Merah sendiri menunjukan hasil produktivitas 3,84 ton/hektare. Sementara itu galur harapan padi hitam yang menjadi fokus dalam penelitian ini menunjukkan hasil produktivitas yang masih jauh dari yang diharapkan. Jika diurutkan produktivitas pada galur harapan padi hitam dari yang terbesar adalah P2 
$(4,10 \pm 0.27$ ton/hektare $), \quad X I \quad(3,95 \pm 0.45$ ton/ hektare), A2 (3,37 \pm 0.36 ton/hektare), BB $(3,27 \pm$ 0.03 ton/hektare), BD $(2,78 \pm 0.12$ ton/hektare $)$, IC $(2,69 \pm 0.05$ ton/hektare $)$, AP $(2,62 \pm 0.36$ ton/ hektare) dan W (2,39 \pm 0.33 ton/hektare).

Galur harapan padi hitam P2 $(4,10 \pm 0.27$ ton/hektare $)$ dan XI $(3,95 \pm 0.45$ ton/hektare $)$ merupakan galur yang memiliki prioritas untuk dikembangkan menjadi varietas padi fungsional berdaya hasil tinggi. Walaupun hasil galur padi hitam tersebut masih kurang jika dibandingkan galur harapan padi putih $\mathrm{H} 360$, namun galur padi hitam P2 dan XI sudah lebih baik daya hasilnya dibandingkan dengan kultivar lokal Sleman Merah. Menurut Senewe dan Alfons (2011) perbedaan produksi total disebabkan oleh perbedaan komposisi genetik dari masingmasing kultivar padi, sehingga respon terhadap lingkungan juga berbeda. Tidak hanya genetik, faktor lingkungan juga berpengaruh pada produksi tanaman, lingkungan yang berpengaruh tersebut berupa cahaya matahari, curah hujan dan unsur hara dalam tanah.

Tabel 6. Heritabilitas dan Koefisien Keragam Genetik Komponen Hasil

\begin{tabular}{llrrcccc} 
No & \multicolumn{1}{c}{ Karakter } & \multicolumn{1}{c}{$\sigma_{g}^{2}$} & \multicolumn{1}{c}{$\sigma_{f}^{2}$} & Heritabilitas $\left(\mathrm{h}^{2}\right)$ & Kriteria & CVg & Kriteria \\
\hline 1 & Umur Berbunga & 44,48 & 47,60 & 0,93 & Tinggi & 0,08 & Sempit \\
2 & Umur Panen & 58,06 & 58,40 & 0,99 & Tinggi & 0,06 & Sempit \\
3 & Tinggi Tanaman & 193,80 & 246,13 & 0,79 & Tinggi & 0,14 & Sedang \\
4 & Panjang Daun Bendera & 32,46 & 43,59 & 0,74 & Tinggi & 0,18 & Sedang \\
5 & Lebar Daun Bendera & 0,02 & 0,05 & 0,40 & Sedang & 0,10 & Sempit \\
6 & Anakan Produktif & 6,54 & 8,11 & 0,81 & Tinggi & 0,16 & Sedang \\
7 & Panjang Malai & 4,84 & 5,05 & 0,96 & Tinggi & 0,08 & Sempit \\
8 & Gabah Isi Per Malai & 996,33 & 1081,00 & 0,92 & Tinggi & 0,25 & Luas \\
9 & Gabah Hampa Per Malai & 62,03 & 77,07 & 0,80 & Tinggi & 0,30 & Luas \\
10 & Gabah Total Per Malai & 1950,67 & 2067,67 & 0,94 & Tinggi & 0,25 & Luas \\
11 & Kepadatan malai & 1,68 & 1,80 & 0,93 & Tinggi & 0,20 & Sedang \\
12 & Bobot 100 butir & 0,05 & 0,06 & 0,83 & Tinggi & 0,10 & Sempit \\
13 & Rendamen & 3,23 & 12,03 & 0,27 & Sedang & 0,02 & Sempit \\
14 & Produktivitas & 1,29 & 1,80 & 0,72 & Tinggi & 0,29 & Luas \\
\hline
\end{tabular}

Pada pendugaan nilai heritabilitas (Tabel 6) terdapat 14 karakter yang diuji. Nilai heritabilitas yang tergolong sedang hanya pada pengamatan rendamen dan lebar daun bendera. Nilai heritabilitas yang tergolong tinggi yaitu karakter umur berbunga, umur panen, tinggi tanaman, panjang daun bendera, anakan produktif, panjang malai, jumlah gabah isi per malai, jumlah gabah hampa per malai, gabh total per malai, kepadatan malai, bobot 100 butir, dan produktivitas. Karakter yang memiliki nilai heritabilitas yang tinggi menunjukkan bahwa pengaruh faktor genetik lebih besar terhadap penampilan fenotip dibandingkan dengan pengaruh lingkungan. Sebaliknya, bahwa karakter yang memiliki nilai heritabilitas rendah disebabkan karena pengaruh lingkungan yang lebih dominan terhadap fenotipiknya dari pada 
pengaruh genetiknya. Seleksi akan lebih efektif jika dilakukan terhadap karakter yang memiliki duga heritabilitas tinggi daripada karekter yang memiliki heritabilitas yang rendah (Falconer and Mackay, 1996).

Menurut Rachmadi (2000), konsep heritabilitas mengacu pada peranan faktor genetik dan lingkungan pada pewarisan suatu karakter tanaman, sehingga pendugaan heritabilitas suatu karakter akan sangat terkait dengan faktor lingkungan. Faktor genetik tidak akan mengekspresikan karakter yang diwariskan apabila faktor lingkungan yang diperlukan tidak mendukung ekspresi gen dari karakter tersebut. Sebaliknya, manipulasi terhadap faktor lingkungan tidak akan mampu menjelaskan pewarisan suatu karakter apabila gen pengendali karakter tersebut tidak terdapat pada populasi.

Menurut Sari et al., (2014) koefisien keragam genetik (Coefficient of variation-CVg) digunakan untuk menduga luas atau tidaknya keragaman genetik yang dimiliki masing-masing karakter. Bila tingkat keragaman genetik sempit maka keragaman antar individu dalam populasi relatif seragam, sehingga seleksi untuk perbaikan sifat menjadi kurang efektif. Sebaliknya, apabila keragaman genetik semakin luas, maka peluang keberhasilan seleksi dalam meningkatkan frekuensi gen yang diinginkan semakin besar pula. Nilai CVg sempit (0-10\%), sedang (10-20\%) dan luas (>20\%) (Knight, 1979).

Karakter umur berbunga, umur panen, lebar daun bendera, bobot 100 butir, rendamen dan panjang malai memiliki nilai koefisien keragaman genetik yang sempit, yang berarti karakter tersebut memiliki keragaman yang relatif seragam dan pengaruh lingkungan tidak menyebabkan perubahan yang nyata. Karakter panjang daun bendera, tinggi tanaman, kepadatan malai, dan anakan produktif memiliki nilai koefisien keragaman genetik yang sedang. Jumlah gabah isi per malai, jumlah gabah hampa per malai, dan produktivitas memiliki nilai koefisien keragaman genetik yang luas.

\section{KESIMPULAN}

Karakter agronomi galur harapan padi hitam secara umum serupa dengan karakter agronomi galur harapan padi putih dan padi merah terkait dengan variabel tinggi tanaman pendek, anakan produktif sedang, umur panen sedang, panjang malai sedang, jumlah gabah per malai kurang dari 250. Daya hasil galur harapan padi hitam P2 $(4,10 \pm 0.27$ ton/hektare $)$ dan XI (3,95 \pm 0.45 ton/hektare) lebih tinggi dari varietas unggul lokal Sleman Merah $(3,84 \pm 0.50$ ton/hektare). Galur harapan padi hitam W (116 \pm 0.33 HSS) memiliki kategori umur panen genjah.

\section{UCAPAN TERIMAKASIH}

Ucapan terimakasih kami ucapkan pula pada tim PIAT UGM dan seluruh teman-teman yang telah membantu dalam melaksanakan kegiatan penelitian.

\section{DAFTAR PUSTAKA}

Abdullah, B., I.S. Dewi, P.L. Lestari, H. Safitri, dan Sularjo. 2008. Seleksi-silang berulang dan kultur antera untuk pembentukan galur padi tipe baru. Laporan Akhir Penelitian tahun 2007. Balai Besar Penelitian Tanaman Padi. 
BB Padi. 2015. Klasifikasi umur padi. <http://bbpadi.litbang.pertanian.go.id/ind ex.php/tahukah-anda/120-kalsifikasiumur-padi>. Diakses 8 April 2019.

Chaudhary, R.C. 2003. Specialty Rices of the World: Effect of wto and ipr on its production trend and marketing. J. Food Agric. Environ. 1(2):34-41.

Dere, S., dan M.B. Yildirim, 2006. Inheritance of grain yield per plant, flag leaf width,and length in an $8 \times 8$ diallel cross population of bread wheat (Triticum aestivum L.). Turkish Journal of Agriculture and Forestry. 30(5):339-345.

Falconer, D.S., and T.F.C. Mackay. 1996. Introduction to Quantitative Genetics, Fourth Edition. Longman, Malaysia.

Knight, R. 1979. Quantitive Genetic Statistics and Plant Breeding. Vice Chancellors Committee. Brisbane, Australia.

Komnas Plasma Nutfah. 2003. Karakterisasi dan Evaluasi Tanaman Padi. Departemen Pertanian, Jakarta.

Kristamtini, S. Widyayanti, Sutarno and Sudarmaji. 2015a. Keragaman genetik lima kultivar lokal padi beras hitam asal Yogyakarta berdasarkan karakter morfologi. Dalam: Prosiding Seminar Nasional Sumber Daya Genetik Pertanian.

Kristamtini, S. Widyayanti, Sutarno, Sudarmaji, dan E.W. Wiranti. 2015b. Pelestarian partisipatif padi beras hitam lokal di
Yogyakarta. Dalam: Prosiding Sumber Daya Genetik Pertanian.

Rachmadi, M. 2000. Pengantar Pemuliaan Tanaman Membiak Vegetatif. Universitas Padjajaran, Bandung.

Sajak, A. 2012. Karakterisasi morfologi malai plasma nutfah padi lokal asal Kabupaten Tana Toraja Utara, Sulawesi Selatan. Universitas hasanuddin, Sulawesi Selatan.

Sari, W. Paramita, Damanhuri dan Respatijarti. 2014. Keragaman dan heritabilitas 10 genotip pada cabai besar (Capsicum annuum L.). Jurnal Produksi Tanaman. 2(4):301-307.

Senewe, R.E. dan J. B Alfons. 2011. Kajian adaptasi beberapa varietas unggul baru padi sawah pada sentra produksi padi di Seram Bagian Barat Provinsi Maluku. Jurnal Budidaya Pertanian. 7:60-64.

Suprihatno, B., dan A.A. Darajat. 2008. Kemajuan dan Ketersediaan Varietas Unggul Padi. Padi Inovasi Teknologi dan Ketahanan Pangan. Sukamandi: Balai Besar Penelitian Tanaman Padi, Badan Penelitian dan Pengembangan Pertanian.

Susanto, U., A.A. Daradjat, B. Suprihatno. 2003. Perkembangan pemuliaan padi sawah di Indonesia. Jurnal Lit Bang Pertanian. 22(3):125-131. 
Vergara, B.S. 1995. Bercocok tanam padi.

Program Nasional PHT Pusat.

Departemen Pertanian. Jakarta.

Yahumri , A. Damiri, Yartiwi dan Afrizon. 2015.

Keragaan pertumbuhan dan hasil tiga varietas unggul baru padi sawah di Kabupaten Seluma, Bengkulu. Pros Sem Nas Masy Biodiv Indonesia. 1:12171221.

Yoshida, S. 1981. Fundamentals of Rice Crop Science. International Rice Research Institute. Los Banos, Philippines. 